\title{
SOCIO-ECONOMIC POTENTIAL FOR THE DEVELOPMENT OF RURAL GREEN TOURISM IN THE TRANSCARPATHIAN REGION
}

\author{
Kristina Kudak', Viktoriia Levkulych ${ }^{2}$
}

\begin{abstract}
The article examines the activities of households that provide services in the field of rural green tourism in Transcarpathian region. The main prerequisites which helped rural residents to start their own business in the sphere of rural green tourism are analyzed; the main indicators of rural tourism homesteads activity according to COVID-19 and in the pre-crisis period are reviewed; the main factors influencing the realization of social and economic potential of households in rural green tourism and its effective use in crisis situations are revealed. The purpose of the article is to conduct socio-economic analysis and assessment of impact of the main generating and destructive factors affecting the functioning of rural tourist estates in Transcarpathian region, which form the basis for the development of anti-crisis measures to improve their socio-economic potential, which can be used by the owners of rural green estates. Methodology. The study was conducted on the basis of the results of sociological monitoring of owners of rural estates in the Transcarpathian region, conducted by the Transcarpathian Regional Center for Socio-Economic and Humanitarian Research of the National Academy of Sciences of Ukraine in 2021. The monitoring covered 95 respondents, of whom $51.6 \%$ were women and $48.4 \%$ were men. $74 \%$ of the respondents were economically active people between the ages of 35 and 56 . The monitoring was conducted on the basis of the method of personal structured interviews according to a stochastic sample, which is representative for the population of the region at the age of 18 and older. The results of the study confirm that the functioning of the majority of rural tourist estates in the Transcarpathian region, in addition to objectively negative consequences of the crisis COVID-19 is affected by many destructive factors at the micro- and macro level, the elimination of which ensures their functioning in case of recurrence of crisis situations. The results of the study showed that only $4 \%$ of entrepreneurs were able to increase the potential and profitability of their own business during the crisis period. Also $23.7 \%$ of entrepreneurs, despite the crisis, plan to diversify and expand their business in the future. According to the results of sociological research anti-crisis measures to improve the effectiveness of rural tourist estates were developed, such as increasing the level of education and qualifications of owners of rural tourist estates, business diversification and expanding the range of services, reorientation to a new category of consumers, the development of e-tourism, strengthening of integration and cooperation between different economic actors in the region.
\end{abstract}

Key words: households, rural tourist estates, rural green tourism, crisis, COVID-19 pandemic.

JEL Classification: D13, R14

\section{Introduction}

Rural green tourism is an important part of the integrated development of rural areas and one of the effective tools for solving the socioeconomic problems of rural areas. In addition, the development of tourism and entrepreneurship cannot work without the participation and cooperation of businessmen directly and indirectly involved in tourism (Wilson, Fesenmaier, 2001). In the Transcarpathian region the functioning of the tourism and recreation sector largely depends on the effective work of farms that provide services in the field of rural tourism. There are more than 600 rural estates in the

\footnotetext{
Corresponding author:

${ }^{1}$ Transcarpathian Regional Center for Socio-economic and Humanitarian Research

of National Academy of Sciences of Ukraine, Ukraine

E-mail: kristina.kudak@gmail.com

ORCID: https://orcid.org/0000-0002-5886-7139

${ }^{2}$ State University "Uzhhorod National University", Ukraine

E-mail: Victory_Ch@ukr.net

ORCID: https://orcid.org/0000-0002-8839-7182
} 
region, which provides employment in rural areas of the region. In terms of the COVID-19 crisis, this sector of the economy suffered almost the greatest losses compared to other economic activities. According to (Zhang, Yang, Singer, Cui, 2021) each country suffered from COVID-19 differently, and the degree of recovery or containment also varies. However, despite many problems, the COVID-19 pandemic has created an opportunity for the development of rural tourism focused mainly on domestic tourists (Vaishar, Štastná, 2020).

In order to assess the socio-economic potential of owners of green rural estates and to develop effective measures for its implementation in the post-crisis period, the study conducted the following steps:

- the main preconditions for the creation and operation of rural tourist estates in Transcarpathian region are analyzed (such as the main motives of business creation, age and level of education of rural entrepreneurs);

- based on the results of sociological monitoring, the opinion of owners of rural tourist estates on the impact of major disruptive factors on their business in the field of rural green tourism was studied;

- a comparative characterization of the main indicators of rural tourist estates in the pre-crisis and post-crisis period has been carried out;

- the main stimulating factors that positively affected the functioning of rural tourist farmsteads in the crisis have been identified;

- the proposals for the implementation of anticrisis measures to improve the functioning of rural tourist farmsteads in the sphere of rural green tourism are substantiated.

\section{Presentation of the main material}

The functioning of entrepreneurship in the field of rural tourism is influenced by various external and internal factors that affect their activities and determine the extent of which can help to implement effective measures to reduce the negative impact on business development and increase its effectiveness.

(Barkauskas, Barkauskienè, Jasinskas, 2015) accent to five groups of macro environmental factors that influenced the functioning of tourism entities, such as economic, socio-cultural, naturalecological, political-legal and technological factors. The results of another research of these scientists (Snieška, Barkauskienè, Barkauskas, 2014) revealed that the number of guests in rural farmsteads is strongly affected by all economic factors (except inflation): GDP per capita, average monthly gross earnings, foreign direct investments, government spending and income, material investment per capita. Meanwhile, the development of rural farmsteads is strongly influenced by average monthly gross income, foreign direct investment, and government spending.

A lot of authors pay attention to the role of integration as an important factor that influencing the functioning of business units in the field of tourism. The findings of (Lun, Pechlaner, Volgger, 2016) indicate that the integration of tourism and agriculture greatly contributes to the authentic tourism experiences. Moreover, leadership, cross-sectoral networks, a shared focus on quality, and effective communication appear to be key success factors for overcoming potential obstacles to rural tourism development.

(Tsephe, Obono, 2013) focus on internal factors affecting the functioning of tourism subjects and have developed a model of factors affecting the motivation of rural tourists, in an attempt to improve understanding of rural tourism motivation to develop this type of tourism. In this article, based on the results of sociological monitoring (Pitjulych, 2021) in order to determine the main motives that prompted the owners of rural tourism entities in Transcarpathia region to provide services in the field of rural tourism, respondents were asked the question "Could you indicate your own motives for starting business?". According to the survey, $41.7 \%$ of respondents were motivated to start their own business by favorable conditions for the development of tourism business in their area (tourist attractions, natural resources, etc.), $20.9 \%$ of respondents were motivated to do business by the example of friends and relatives in the area under analysis. For $19,1 \%$ of respondents, the main motivating factor for opening a tourist estate was the desire to engage in tourism business, while $18,2 \%$ of respondents began to provide services in the field of rural tourism due to unemployment.

One of the tasks of the study was to determine the level of education of owners of tourist estates, which can characterize the level of their training to some extent, awareness and quality of tourist services. According to the results of the survey, it 
was found that $41.5 \%$ of rural estate owners have higher education, 34\% have special education, and $21.3 \%$ have secondary education. Only $3.2 \%$ are qualified in the field of tourism, which indicates an insufficient level of qualification of business owners in the analyzed area and requires active measures to improve their educational level in the field of tourism.

To identify destructive factors hindering the development of rural tourism and the functioning of tourist estates in the Transcarpathian region, respondents were asked the following question "What problems do you face when running your own business?" The following answers were obtained: $34.7 \%$ of respondents pointed to low consumer demand (due to the COVID-19 crisis), but it should be noted that compared to the precrisis period, this factor was not decisive in the activities of owners of tourist estates. $21.9 \%$ of respondents pointed to the underdeveloped transport infrastructure, $22 \%$ pointed to the high cost of resources, $6.9 \%$ pointed to imperfect legislation, and $5.2 \%$ pointed to high tax rates.

During the monitoring, owners of rural tourist estates were asked, "How has the demand for your services changed over the past 5 years before COVID-19 and after the crisis?" According to the results of sociological monitoring, it was found that for a large part of the owners of rural tourist estates in the period 2015-2019 there was a positive trend of growth in demand for their services, in particular $48 \%$ of respondents (46 people) indicated an increase in demand, of which 15 respondents indicated that demand increased by $70-100 \%$, for 15 respondents increased by $50-70 \%, 11$ respondents indicated an increase of $30-50 \%$ and 5 participants reported an increase of $10-30 \%$. At the same time, $18 \%$ of the respondents noted a $30-50 \%$ decrease in their demand over the analyzed period (Figure 1).

As a result of the impact of the COVID-19 crisis, $89 \%$ of respondents reported a catastrophic decrease in the level of demand for their services. Specifically, among them, $46 \%$ of respondents (44 people) indicated that demand had declined by $70-100 \%, 23$ respondents by $50-70 \%$, 11 respondents by $30-50 \%$, and 7 respondents by $10-30 \%$. Only $4.2 \%$ of owners of tourist farmsteads reported a positive trend in demand growth during the crisis, of which 3 respondents reported a $30-50 \%$ increase in demand and 1 respondent reported a $70-100 \%$ increase in demand (the increase in demand was due to the diversification of activities and the introduction of new services for tourists, including mountain and hiking tourism).

The results of the monitoring showed that in COVID-19 conditions, rural estate owners incurred significant losses due to the lack of diversification of their business and their inability to respond flexibly to new situations and market challenges. Analysis of the results of the answers to the question "What services do you provide to tourists?" shows that $41.8 \%$ of owners of rural tourist farmsteads provide accommodation and meals, $36.4 \%$ of owners only provide accommodation and $14.5 \%$ of respondents

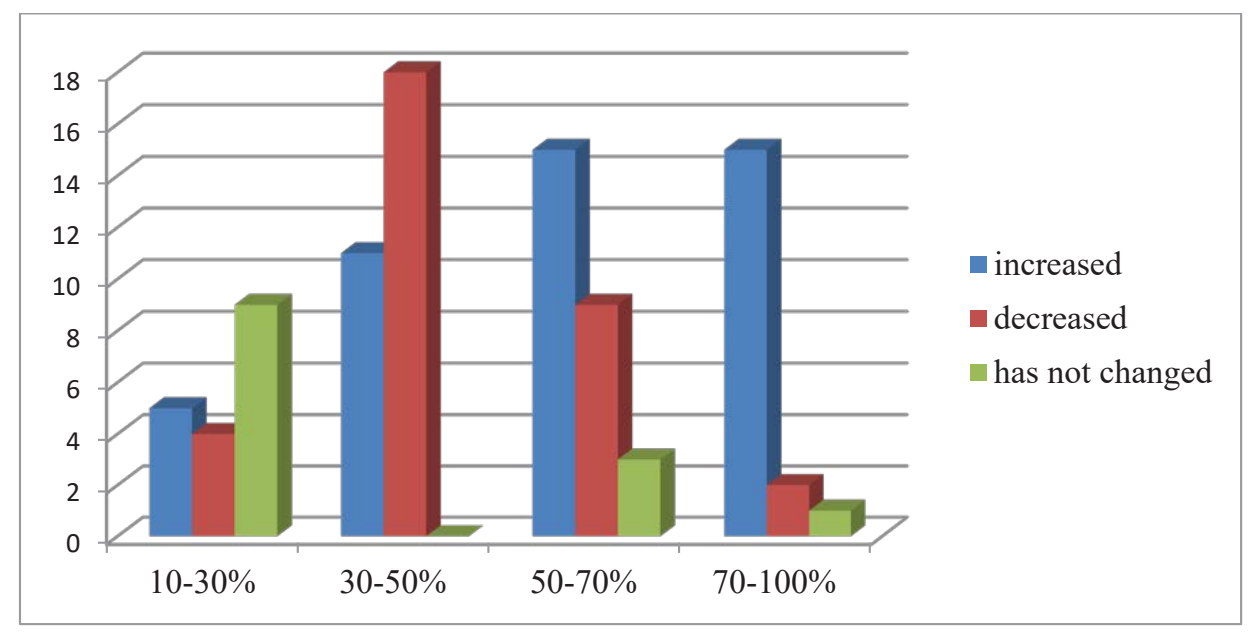

Figure 1. The answers for the question "How has the demand for your services changed over the past 5 years before COVID-19 and after the crisis?"

Source: based on the results of sociological monitoring 
answered that they offer additional services such as hunting, fishing, transfers, excursions, etc.

Monitoring the level of income of owners of tourist real estate showed that because of the crisis COVID-19 most businesses have reduced income by almost $90-100 \%$, but a significant number of respondents did not want to answer this question, considering such information confidential. The results of the monitoring revealed that for more than $81 \%$ of respondents the level of income is less than 300EUR in the summer season, $70 \%$ of respondents in the winter season and $83 \%$ in the off-season. The level of income in the amount of 300-1000 EUR is received by $15 \%, 18 \%$ and $12 \%$ of respondents respectively in the summer, winter and offseason periods. According to the results of the monitoring, only $4 \%, 12 \%$, and $5 \%$ of the respondents (respectively, in summer, winter, and off-season) receive the amount of income between 1,000 and 1,500 EUR.

An analysis of the price level of rural entrepreneurs' rental services shows a relatively stable price level in all seasons of the year that is about 10 euros/day, as indicated by $69.4 \%, 45 \%$, $65.9 \%$ of respondents (in summer, winter and off-season, accordingly). According to the results of the monitoring, most owners of rural tourism farmsteads have not significantly changed the prices for their services because of the crisis, in particular, $74.7 \%$ of respondents have not changed their prices, $12.6 \%$ of respondents have reduced prices by $10 \%, 5.2 \%$ of respondents by $10-30 \%$ and only $3.1 \%$ by $30-50 \%$ (Figure 2 ).

Assessing the impact of COVID-19 crisis on the functioning of tourism entities, in order to determine the prospects and directions of development of rural entrepreneurship in tourism, business representatives were asked the question "What are your plans for the development of your business in the future?" (Figure 3 ).

The results of the responses in Figure 3 show that in the post-crisis period, $61.3 \%$ of the respondents do not plan to change anything in their business, $10.8 \%$ want to close their business, $3.2 \%$ want to cut it. On the other hand, despite the impact of the COVID-19 crisis, $23.7 \%$ of entrepreneurs want to expand their business and diversify rural tourism services.

\section{Anti-crisis measures to stimulate entrepreneurial potential in the field of rural green tourism}

In time of the COVID-19 crisis, scholars have also reflected on the model of tourism development during a pandemic, believing that it provides new opportunities for sustainable tourism development (Cheer, 2020). According to Lane B., the concept of sustainable rural tourism must be multi-purpose if it is to be successful. It should focus on maintaining the culture and character of the host communities, maintaining the landscape and habitat, sustaining the rural economy, and developing enough understanding,

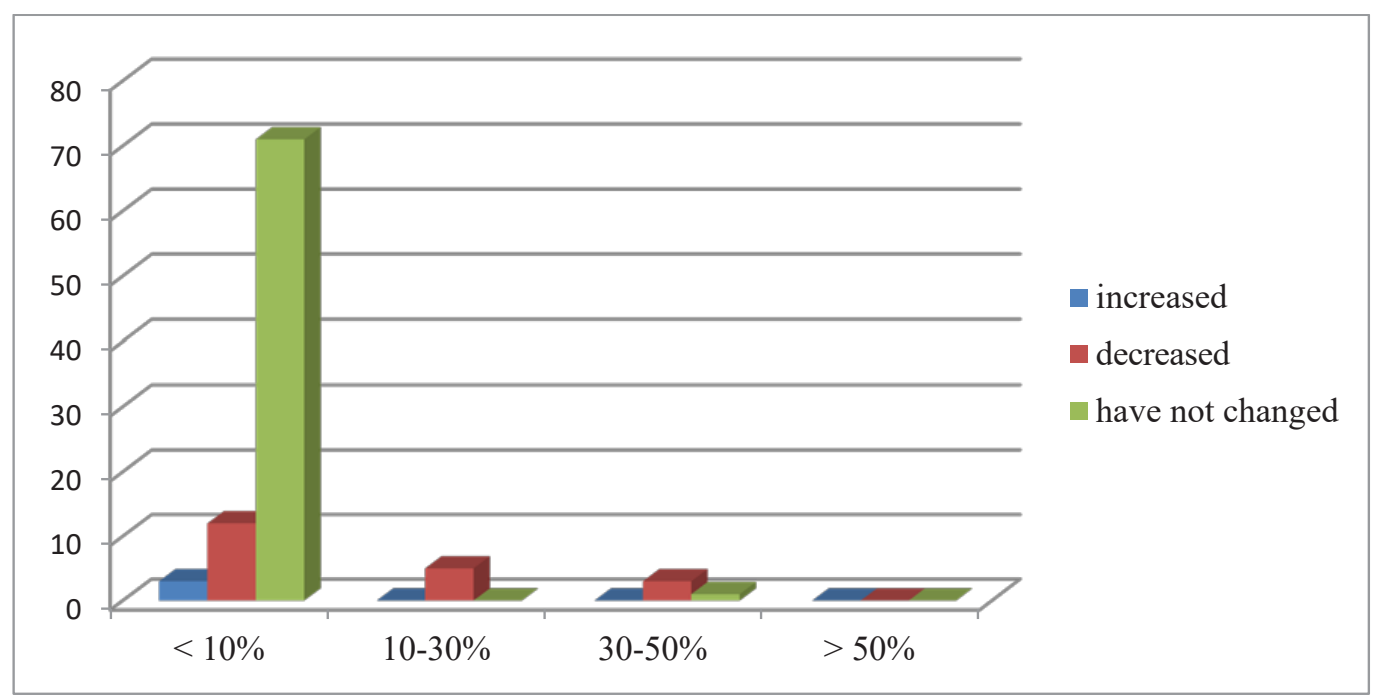

Figure 2. Answers to the question "How did prices for your services change in the pre-crisis period (before the COVID-19 crisis)?"

Source: based on the results of sociological monitoring 


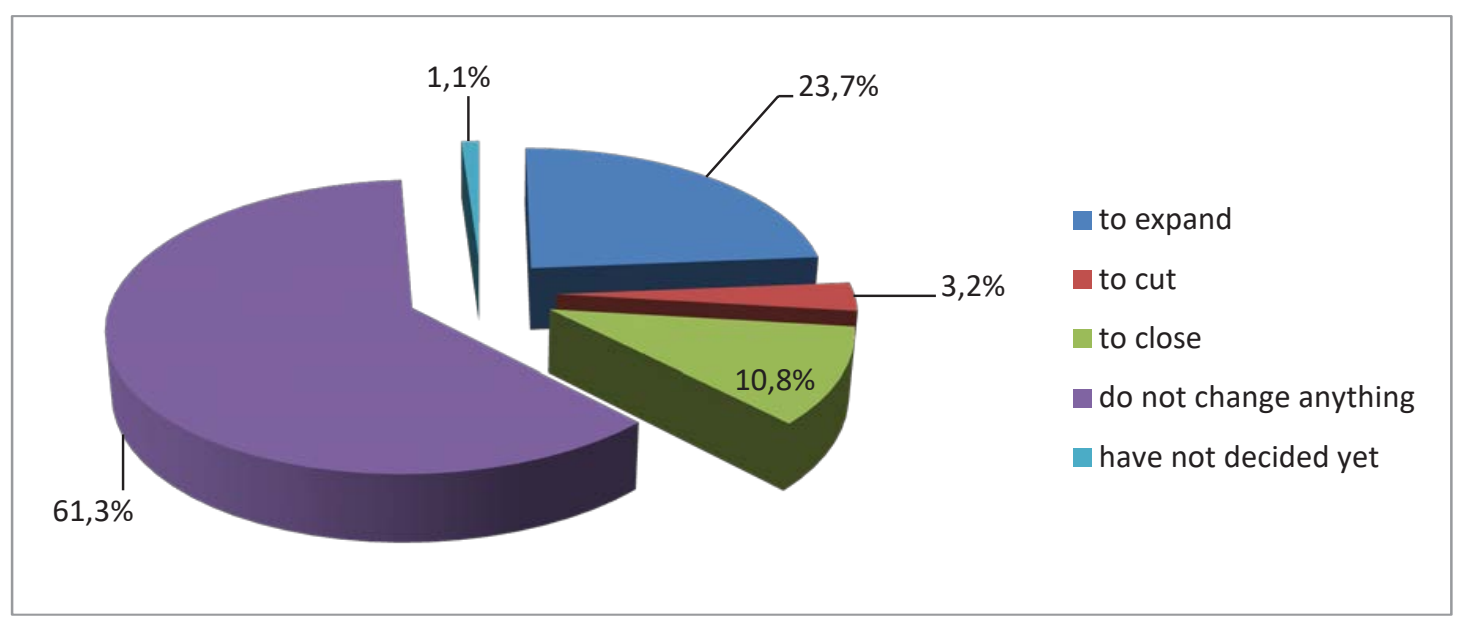

Figure 3. Responses to the question

"What are your plans for the development of your business in the future?"

Source: based on the results of sociological monitoring

leadership, and vision among the region's decision makers to recognize the dangers of relying too heavily on tourism and to continue to work toward a balanced and diversified rural economy (Lane, 2005).

The tourism sector, in terms of crisis management, is more exposed to specific crisis factors than other sectors for several reasons: it is highly people-oriented; the behavior of a tourist destination is unpredictable and therefore more difficult to control, in case of disaster; most tourists face a lack of information about the vacation destination; the tourism industry is highly fragmented, not easy to respond to disasters (Roozen, 2010). That is why the task of crisis management is the formation of a system of measures to foresee possible negative trends and phenomena (external and internal), the analysis of the probability of their occurrence, assessment of their possible impact on the activities of the subject of management and the maximum elimination of destructive consequences. The parallel mediating effect of risk perception and risk aversion attitudes in rural tourism must be considered together ( $\mathrm{Zhu}$, Deng, 2020).

According to (Biletska, 2016) a separate area of crisis management should be the development of a so-called "SOS package" for truly unpredictable natural (hurricanes, earthquakes, floods, etc.) and man-made (outbreaks of epidemics, terrorism, industrial fires, etc.) disasters. In general, crisis management must take into account internal and external factors, and include several areas such as pre-crisis, crisis and post-crisis management. It is important to stabilize unstable situations and minimize losses and missed opportunities, which tourism business owners should pay attention to.

Measures proposed in the EU to support the tourism industry can be divided into three main categories: ensuring a fair balance between the protection of tourists and tourism industry stakeholders; providing living conditions for businesses with a special focus on SMEs; focus on coordination mechanisms to support and restore the tourism sector (COVID-19, 2020).

At the micro-level, according to (Kostynets, 2020) components of the mechanism of development and implementation of anticrisis measures of tourism enterprises should include the following: stimulation of consumer demand in domestic tourism, development and use of incentive programs for regular customers and partners, in particular the formation of pent-up demand for future tourist seasons; implementation of new opportunities of Internet technologies (improvement of companies' websites), full transition to electronic document management, optimization of work in messengers and social networks; improving the quality of services and offers of related services in tourism (remote business training, consultations on crisis management in tourism, professional webinars, etc.); transfer of personnel to remote work and revision of the personnel remuneration system (calculation of wages depending on performance); development and offer of new tourist routes with 
an emphasis on insider tourism; cooperation with insurance companies in terms of offering clients trip cancellation insurance.

Taking into account existing proposals and based on the results of a sociological survey of owners of rural homesteads, the main anti-crisis measures for owners of rural tourism homesteads at the micro-level should include the following: - improving the level of education and qualifications of owners of rural tourist estates, such as attending seminars, trainings and special courses (managers, guides, etc.), which will give an impetus to the development of management skills in the tourism business;

- expansion of the range of services. In particular, in the COVID-19 crisis, implementation and development of tourist activities in the open air and in nature (hiking and mountain climbing, sightseeing in national parks and nature reserves; creation of tourist attractions in the open air (playgrounds, mini-parks, recreation areas, ponds, etc.));

- reorientation to a new category of consumers of tourist services who are not at risk of exposure to COVID-19 (young people, children and young families), and the strengthening of quarantine measures (additional conditions for tourists of retirement age, such as social distancing, construction of housing not involving crowding, the use of additional sanitary and hygienic measures in rural estates, etc.);

- the development of e-tourism and the use of digital technology (online booking, -booking, -payment, etc.);

- strengthening relations of cooperation between various economic entities in the field of tourism and other activities (carriers, catering companies, insurance companies) and the authorities, which will contribute to the development of tourism infrastructure.

\section{Conclusions}

The study showed that the functioning of rural tourist estates in the Transcarpathian region in the field of rural green tourism both in the crisis and in the pre-crisis period was influenced by factors that affected their activities. The analysis confirms that the main stimulating factors are favorable conditions for the development of tourism business, appropriate educational level of owners of rural tourism farmsteads, stable level of demand for services of rural entrepreneurs (in the pre-crisis period), the ability to respond flexibly to changes in market conditions. Among the disruptive factors are underdeveloped infrastructure, high cost of resources, imperfect legislation, insufficient introduction of new services, such as digital and online technologies. To reduce the impact of these factors it is necessary to apply anti-crisis measures to improve the socio-economic potential of tourist estates, including business diversification, reorientation to new consumers and improving the quality of services, the use of online services. Priority should be given to improving the skills of owners of rural green estates and the development of cooperative links with other tourism businesses to develop tourism infrastructure in rural areas of the region. Discussion. It is ambiguous to determine the degree of influence of the analyzed factors on the activities of rural entrepreneurs, given that a certain part of the respondents during the crisis period could reduce the level of exposure to negative factors. According to this statement, future studies should focus on studying the degree of influence of positive and negative factors on the activities of subjects of rural tourism and the development of a mathematical model that would reflect this dependence.

\section{References:}

Barkauskas, V., Barkauskienè, K., \& Jasinskas, E. (2015). Analysis of macro environmental factors influencing the development of rural tourism: Lithuanian case. Procedia-Social and Behavioral Sciences, 213, 167-172.

Biletska, I. (2016). Atikrizovij menedzhment u turizmi [Anticrisis management in tourism]. Available at: http://www.economy.nayka.com.ua/?op=1\&z=4898

Cheer, J. M. (2020). Human flourishing, tourism transformation and COVID-19: A conceptual touchstone. Tourism Geographies, 22(3), 514-524.

COVID-19 ta social'nij dialogv turistichnij galuzi: praktika ES ta ukrainski realiji [COVID-19 and social dialogue in the tourist industry: EU practice and Ukrainian realities]. 
Kostynets, V. (2020). Mekhanizm antikrizovogo menedzhmentu u turistichnomu biznesi [Mechanisms of anti-crisis management in tourism business]. Available at: https://ir.kneu.edu.ua/ bitstream $/$ handle $/ 2010 / 32886 /$ sism_20_71-74.pdf? sequence $=1$

Lane, B. (2005). Sustainable rural tourism strategies: A tool for development and conservation. Interamerican Journal of Environment and Tourism, 1(1).

Li, Z., Zhang, X., Yang, K., Singer, R., \& Cui, R. (2021). Urban and rural tourism under COVID-19 in China: research on the recovery measures and tourism development. Tourism Review.

Lun, L. M., Pechlaner, H., \& Volgger, M. (2016). Rural tourism development in mountain regions: Identifying success factors, challenges and potentials. Journal of Quality Assurance in Hospitality \& Tourism, 17(4), 389-411.

Pitjulich, M. (2021). Potentsial rozvytku turystychno-rekreatsiinoho kompleksu silskykh terytorii Zakarpatskoi oblasti [Potential of the development of the tourist and recreational complex of rural areas of Transcarpathia]. Analytical report on project work of ZRC SEHD NAN Ukraine.

Roozen, I. (2010). The Effectiveness of Product Placements in Music Videos: Some Experimental Empirical Results. Romanian journal of marketing, 3, 7-32.

Snieška, V., Barkauskienè, K., \& Barkauskas, V. (2014). The impact of economic factors on the development of rural tourism: Lithuanian case. Procedia-Social and Behavioral Sciences, 156, 280-285.

Tsephe, N. P., \& Obono, S. E. (2013). A theoretical framework for rural tourism motivation factors. International Journal of Economics and Management Engineering, 7(1), 273-278.

Vaishar, A., \& Štastná, M. (2020). Impact of the COVID-19 pandemic on rural tourism in Czechia Preliminary considerations. Current Issues in Tourism, 1-5.

Wilson, S., Fesenmaier, D. R., Fesenmaier, J., \& Van Es, J. C. (2001). Factors for success in rural tourism development. Journal of Travel research, 40(2), 132-138.

$\mathrm{Zhu}, \mathrm{H}$., \& Deng, F. (2020). How to influence rural tourism intention by risk knowledge during COVID-19 containment in China: mediating role of risk perception and attitude. International journal of environmental research and public health, 17(10), 3514. 